\title{
Discovery of the PTEN Tumor Suppressor and Its Connection to the PI3K and AKT Oncogenes
}

\author{
Ramon Parsons \\ Department of Oncological Sciences, Tisch Cancer Institute at Mount Sinai, Icahn School of Medicine \\ at Mount Sinai, New York, New York 10029, USA \\ Correspondence: ramon.parsons@mssm.edu
}

PTEN (phosphatase and tensin homolog on chromosome 10) was discovered over 20 years ago in 1997 and linked to the phosphatidylinositol 3-kinase (PI3K) and AKT oncogenes the following year. The discovery of PTEN emerged from the linked concepts of oncogenes and tumor suppressor genes that cause and prevent cancer and the fields of tumor viruses and human cancer genetics from which these two concepts arose. While much has been learned since, the initial discovery and characterization, including the discovery that PTEN is a regulator of PI3K and AKT, provide the foundation on which we continue to build our knowledge. To provide the context in which these cancer genes were discovered, background information that led to their discovery will also be discussed, which will hopefully be a useful guide for readers seeking to build on the work of others.

\section{THE ONCOGENE CONCEPT AND EVIDENCE TO SUPPORT IT}

The oncogene concept emerged from the
tumor virus field, which developed over a
60 -year period from the discovery of the first
cancer-causing virus in chickens at the begin-
ning of the twentieth century (Rous 1911). By
the 1950s, it had been established that there were
many different independent types of mammali-
an viruses that could cause cancer (Gross 1974).
Their names were often eponymous and a con-
sequence of their species tropism and the type of
cancer that they caused. By the 1960s, it was
clear that polynucleotides from the different vi-
ruses carried the genetic information needed to
infect and transform cells, and tumor viruses
were broadly divided into the DNA and RNA tumor viruses based on the type of polynucleotide packaged in the virus particle (Javier and Butel 2008). The idea that genes could cause cancer was an extremely old one (Rous 1911), but the evidence was difficult to acquire because it required the isolation of the viral gene that was capable of causing a tumor, which was dependent upon technological innovation. The technology to measure the ability of viral particles and their clonal progeny to cause cellular transformation in tissue culture was developed in the 1960s, which allowed for viral cloning and characterization of their ability to cause cancer (Dulbecco 1960). With isolated cloned viruses in hand, the new technologies of DNA restriction enzymes and bacterial cloning, which were developed in the 1970s, allowed for the isolation of the viral genes that caused cancer. In 1975, the

Editors: Charis Eng, Joanne Ngeow, and Vuk Stambolic

Additional Perspectives on The PTEN Family available at www.perspectivesinmedicine.org

Copyright (C) 2020 Cold Spring Harbor Laboratory Press; all rights reserved; doi: 10.1101/cshperspect.a036129

Cite this article as Cold Spring Harb Perspect Med 2020;10:a036129 


\section{R. Parsons}

first oncogene was isolated by three groups who independently discovered that the "A gene" of SV40 virus, which had been determined to encode the large T-antigen a few years earlier, was the cancer-causing gene (Brugge and Butel 1975; Martin and Chou 1975; Tegtmeyer 1975). The proof that the gene encoding large T-antigen was the SV40 oncogene was obtained through the mapping of the SV40 A gene to a temperature-sensitive mutation that was able to conditionally cause cellular transformation at the permissive temperature and revert to normal morphology at the higher nonpermissive temperature. Further mapping determined that the SV40 gene encoding small T-antigen was also an oncogene. Analysis of the polyoma virus oncogenes showed that like SV40 it also had small and large T-antigens; however, in addition, the virus had an additional potential oncogene encoding middle T-antigen (Lania et al. 1979; Treisman et al. 1981).

A similarly behaving temperature-sensitive mutation of Rous sarcoma virus was identified in 1970 (Martin 1970), but because of the difficulty of mapping genes to RNA, it was not until 1976 that the mutation could be mapped to a specific gene (Bernstein et al. 1976). In the same month, another group used an entirely different method for mapping the oncogene, termed $s r c$, for the virus by showing that the transforming form of the virus contained genetic information homologous to chicken and other avian species, which provided the first evidence that cellular genetic information could be oncogenic in viruses (Stehelin et al. 1976).

In 1982, the first oncogene derived from mammalian cells and not a virus was cloned from human cancer cells by isolation of a DNA fragment capable of transforming immortal mouse fibroblasts (Cox and Der 2010). It was recognized that the transforming human gene was homologous to the transforming gene from the rat sarcoma virus genome and contained similar point mutations. Two forms of ras oncovirus (Harvey and Kirsten) were found to have distinct human homologs. Excitingly, the KRAS oncogene was somatically mutated at high frequency in human colon cancer. In a similar time frame, human homologs of other RNA tumor virus oncogenes such as $m y c, a b l$, and erbbl and erbb2, were found also to be mutated into active forms by translocation and amplification that occurred in the tumor cell. The above advances were aided by new technologies for genetics and molecular biology including gel electrophoresis, Southern and northern blotting, reverse transcriptase, restriction enzymes, recombinant cloning in bacterial vectors, and DNA sequencing.

One of the pressing questions of the time was to understand how these oncogenes were able to cause cancer. Pertinent to this story, one of the first insights came from work with polyoma middle T-antigen. Antibodies to middle T-antigen were able to coprecipitate $s r c$ protein and its associated tyrosine kinase activity from cells (Smith et al. 1979; Courtneidge and Smith 1983). This was an exciting finding since it was the first to link the DNA tumor virus oncogene to an oncogenic protein from an RNA tumor virus. Antibodies to middle T-antigen were also shown to coprecipitate with another enzyme activity able to phosphorylate the lipid phosphatidylinositol in vitro (Whitman et al. 1985). Middle T-antigen's transformation activity was dependent on its ability to interact with the lipid kinase activity (Kaplan et al. 1986) and soon thereafter a human cellular phosphatidylinositol kinase activity was isolated that was distinct from src and middle T-antigen, which specifically phosphorylated the third alcohol of phosphatidylinositol 4,5-bisphosphate on the lipid's inositide head group, thus leading to the name phosphatidylinositol 3-kinase (PI3K) (Whitman et al. 1987, 1988).

\section{THE TUMOR SUPPRESSOR CONCEPT AND EVIDENCE TO SUPPORT IT}

Like the idea of the oncogene, the concept of the tumor suppressor is over a century old (Hansford and Huntsman 2014). The first functional evidence for tumor suppression came from cell fusion experiments, which showed that normal cells fused with cancer cells could suppress cancer formation (Harris et al. 1969). However, Knudson developed the concept further in his effort to understand the basis for the difference 
between early- and late-onset pediatric retinoblastoma by positing that the early-onset disease was associated with inheritance of a mutant autosomal allele followed by loss of the wild-type allele at the time of tumor initiation and that the late-onset form required that both copies were altered after birth (Knudson 1971). However, the precise localization of a tumor suppressor gene had to await the mapping to the gene responsible for retinoblastoma. Karyotypes from patients with retinoblastoma revealed that some patients had small deletions within chromosome 13q (Orye et al. 1974). Use of DNA fragments mapping to chromosome 13 revealed that loss of heterozygosity (LOH) could be detected in retinoblastoma samples compared to normal DNA from the same patient (Cavenee et al. 1983). In 1986, a key paper that was the culmination of years of effort to isolate and locate the gene responsible for retinoblastoma $(R B 1)$ was published (Friend et al. 1986). Importantly, unlike the previously mentioned oncogenes that are defined by their ability to cause cancer, the RB1 gene was the first example of a tumor suppressor gene, which is defined by its ability to guard against and suppress cancer development. Restoration of RB1 into retinoblastoma cell lines was later shown to suppress cancer growth (Huang et al. 1988). The location of the responsible gene was made possible by mapping from retinoblastoma cases a region of minimal $\mathrm{LOH}$ to identify the approximate gene locus followed by mapping of smaller homozygous deletions where both copies of DNA were deleted. The DNA fragments that were only present in wild-type cells were used to identify and clone the RB1 transcript by hybridizing them to a human cDNA library cloned into bacteriophage. In 1987, the encoded RB1 protein was found to encode a protein of $110 \mathrm{kDa}$ (Lee et al. 1987a, 1987b).

Like SV40 and polyomavirus, adenovirus, another DNA tumor virus, was found to encode oncogenes, one of which was E1A. Ed Harlow at Cold Spring Harbor and his Stony Brook graduate students determined that an antibody to E1A could coprecipitate with a cellular 110 $\mathrm{kDa}$ protein (Harlow et al. 1986). Soon thereafter, they determined that this protein was the
RB1 protein, which was the first time a viral oncoprotein was found to interact with a tumor suppressor protein (Whyte et al. 1988). Soon thereafter, SV40 large T-antigen was found to interact with RB1 as well (DeCaprio et al. 1988).

Another very enlightening discovery, which occurred the following year, was the demonstration that $\mathrm{p} 53$, another cellular protein-binding partner of SV40 large T-antigen, an interaction that was first identified in 1979 by multiple groups, was encoded by a tumor suppressor gene (Levine and Oren 2009). Mapping of LOH in colon cancer identified a minimal region of loss where the gene for $\mathrm{p} 53$ was located on chromosome $17 \mathrm{p}$. Sequencing of two colon cancers having a loss of one allele determined that the remaining allele had a p53 mutation (Baker et al. 1989). Functional studies showed that wild-type p53 suppressed tumor cell growth (Baker et al. 1990). Soon thereafter, it was determined that the p53 gene was mutated in affected individuals in families with the Li-Fraumeni cancer predisposition syndrome (Srivastava et al. 1990). Thus, it was now apparent that the DNA tumor virus transformed normal cells at least in part by disrupting two tumor suppressor proteins $\mathrm{RB} 1$ and $\mathrm{p} 53$.

\section{IDENTIFICATION OF THE PI3K/PTEN PATHWAY}

Tumor Viruses and the Discovery of the PI3K and AKT Oncogenes and Oncoproteins

The foundational discovery identifying and showing that the PI3K pathway was activated in cancer came from the study of immunoprecipitates of the polyoma middle T-antigen oncoprotein that were found to coprecipitate with a kinase activity capable of phosphorylating phosphatidylinositols by the mid-1980s. Further characterization of mutations of middle T-antigen determined that the interaction with the inositol kinase activity was required for it to behave as an oncogene. Analysis of the new enzyme determined that it specifically phosphorylated the third position of the inositol ring of the plasma membrane phospholipid, phosphatidylinositol 4,5-bisphosphate and that it had 
two components, one of $110 \mathrm{kDa}$ that was the catalytic subunit and another of $85 \mathrm{kDa}$ that was the regulatory subunit, that were encoded by separate genes, now known as PIK3CA and PIK3R1 (Whitman et al. 1988; Carpenter et al. 1990). Based on these features, the enzyme was named PI3K. Moreover, the kinase was determined to be activated rapidly within seconds in response to a wide range of extracellular signals including insulin and platelet-derived growth factor (PDGF), which led to the accumulation of its product phosphatidylinositol-3,4,5-trisphosphate $\left(\mathrm{PIP}_{3}\right)$, which was short-lived, and presumed to act as a second messenger to signal to other proteins (Whitman et al. 1987). PI3K, which is known as PI3Ko, was the first member of the large family of enzymes in this class including the closely related $\mathrm{PI} 3 \mathrm{~K} \beta, \mathrm{PI} 3 \mathrm{~K} \gamma$, $\mathrm{PI} 3 \mathrm{~K} \delta$, and more distantly related $\mathrm{mTOR}$ and ATM, among others. Independent evidence that $\mathrm{PI} 3 \mathrm{~K} \alpha$ acts an oncogene came from multiple sources including the isolation of PIK3CA, which encodes the $\mathrm{p} 110 \alpha$ catalytic subunit, as a chicken retrovirus oncogene in 1997 (Chang et al. 1997), and the later discovery of mutations of human PIK3CA, which often occurred in common cancers at rates that are very high, particularly in breast cancer (Campbell et al. 2004; Samuels et al. 2004; Saal et al. 2005). Importantly, these mutations not only activated the enzyme, they also could transform cells and cause cancer in different model systems with the most common hotspot mutations occurring in PIK3CA at codons 542, 545, and 1047 (Bader et al. 2006). In addition to being activated through extracellular signals, the p110 kDa catalytic subunit has an RAS-binding domain through which RAS oncoproteins can bind and activate PI3K directly. PIK3CA mutations are most commonly found in estrogen receptor (ER)-positive breast cancer (Saal et al. 2005), and inhibition of PI3Ka in these tumors with a $\mathrm{PI} 3 \mathrm{~K} \alpha$ selective inhibitor in combination with inhibition of the ER has recently been shown to have benefit for patients with metastatic cancer with this genotype (Juric et al. 2019).

The AKT8 mouse RNA tumor virus was first isolated in 1977 by Stephen Staal from a strain of AKR mice prone to spontaneous lymphoma.
Ten years later, in 1987, he sequenced the viral genome and identified that it contained a putative oncogene that was homologous to two human genes, of which one, AKT1, was amplified in a subset of some human cancers. Soon thereafter, AKT2 was also found to be amplified in other cancer types (Bellacosa et al. 1995; Cheng et al. 1996). AKT was discovered to be a serinethreonine protein kinase in 1991 (Bellacosa et al. 1991) and shown to be regulated by PI3K (Franke et al. 1995). The molecular link between PI3K and AKT was determined in 1997 when it was shown that the PH domain of AKT could bind specifically to the product of $\mathrm{PI} 3 \mathrm{~K}, \mathrm{PIP}_{3}$, which was required for plasma membrane binding and activation of the kinase activity of AKT (Franke et al. 1997). Interestingly, a hotspot oncogenic mutation of AKT1 (E17K) alters the PH domain pocket, thus bringing the mutant protein to the plasma membrane (Carpten et al. 2007).

The AKT kinase has a wide range of target proteins within the cell that have varied physiological and oncogenic effects, which is beyond the scope of this review. However, one of the main AKT targets involved in cancer is the mTOR protein complex TORC1, which is inhibited by the TSC1 and TSC2 tumor suppressors. Activated AKT phosphorylates TSC2, which leads to the degradation of the TSC1/TSC2 complex, as well as the TORC1 subunit PRAS40, and allows for activation of TORC1 kinase, which has a variety of progrowth effects on the cell that stimulate lipid, nucleotide, and protein synthesis (Inoki et al. 2002; Manning et al. 2002; Tee et al. 2002).

\section{Tumor Suppressor Gene on Chromosome 10}

As discussed above, the concept of tumor suppressor genes emerged from the field of human cancer genetics that mapped specific germline and somatic chromosome alterations in earlyonset cancer predisposition syndromes such as retinoblastoma and the field of tumor cell biology that showed that fusion of normal cells with cancer cells or expression of a tumor suppressor gene from an expression vector could suppress cancer cell growth. The discovery of the RB1 
tumor suppressor in 1986 using these technologies elicited a large-scale search for other tumor suppressor genes.

Studies of the karyotypes of glioblastoma multiforme tumor cell lines by Darryl and Sandra Bigner at Duke University determined that these cells lost one copy of chromosome 10 at a frequency that was much higher than seen for other chromosomes (Bigner et al. 1984). Analysis of allelic losses by the Cavenee and Bigner laboratories in 1988 comparing glioblastoma biopsies and normal tissue DNA determined that $\mathrm{LOH}$ for chromosome 10 occurred at high rates in glioblastoma but was not seen in lower grade astrocytomas (Bigner et al. 1988; James et al. 1988). Mapping studies to locate a minimal region of chromosomal loss implicated the long arm of chromosome 10 (Rasheed et al. 1992). Inspired by these genetic mapping studies in glioblastoma samples, normal chromosome 10 from fibroblasts was fused to glioblastoma cell lines, which suppressed tumor cell growth in soft agar and in mice; control experiments that fused chromosome 2 did not suppress tumor growth (Pershouse et al. 1993).

The relevance of chromosome 10 to other types of cancer was soon realized. An analysis of prostate cancer allelic loss patterns determined that loss of chromosome 10q was a frequent occurrence (Gray et al. 1995). This was soon followed by a linkage analysis study that determined that the hereditary cancer predisposition syndrome known as Cowden disease (or syndrome) was linked to chromosome 10q2223 (Nelen et al. 1996), a segment contained within a previously implicated region found in tumor LOH studies. Cowden syndrome is associated with increased risk for the development of benign neoplasms known as hamartomas, but also cancer, including cancers of the breast and thyroid (see Ngeow and Eng 2019).

Based upon the high frequency of chromosome losses in glioblastoma and prostate cancer and the linkage to the cancer predisposition syndrome Cowden syndrome, there was a high index of suspicion that chromosome 10 harbored one or more tumor suppressor genes that might be broadly relevant to multiple types of human cancer. Efforts to isolate the gene using positional cloning methodologies were undertaken in multiple laboratories. One approach to isolate the gene was to use cell fusions that contained chromosome 10 fragments to identify the minimal region able to suppress tumor cell growth (Steck et al. 1995). Another approach was to use microsatellites to map a minimal region of $\mathrm{LOH}$. Both of these approaches were limited in resolution and led to multiple different candidate regions containing a possible tumor suppressor gene.

Alternatively, mapping of tumor homozygous deletions, which are much smaller than heterozygous deletions, as a means to isolate a relatively small region containing only one gene was a powerful method for identifying tumor suppressor genes and had been previously used for the identification of the RB1, CDKN2A, and SMAD4 tumor suppressor genes (Friend et al. 1986; Kamb et al. 1994; Hahn et al. 1996). Therefore, it seemed reasonable to scan the whole genome for homozygous deletions in cancer samples utilizing a genomic subtraction method known as representational difference analysis that identified probes present in a normal genome but not in the matched tumor (Lisitsyn et al. 1993). Probes identified from the subtraction were mapped using radiation hybrids to different parts of the genome and tested for recurrent homozygous deletion in other cancer cases ( $\mathrm{Li}$ et al. 1997). One of the genomic probes representing a possible homozygous deletion in a breast cancer mapped to the $10 \mathrm{q} 23$ region of $\mathrm{LOH}$ and linkage identified in glioblastoma, prostate, and Cowden syndrome. Mapping of allelic losses in breast cancer also determined that chromosome $10 \mathrm{q} 23$ was a region of $\mathrm{LOH}$ in nearly $40 \%$ of cases; however, this initial probe was not able to identify homozygous deletions in any of the samples tested $(\mathrm{Li}$ et al. 1997).

The key genomic means for cloning PTEN was identified by cataloging as many probes as possible in the $10 \mathrm{q} 23$ region and examining them for recurrent homozygous deletion in a panel of 65 breast cancer cell lines and xenografts (Li et al. 1997). One probe from this region AFMA086WG9 was homozygously deleted in two xenografts from these 65 cases. When it was tested in prostate and glioblastoma samples, 


\section{R. Parsons}

it was also completely missing in multiple glioblastoma and prostate cancer cell lines and glioblastoma xenografts. The probe was then used to isolate multiple bacterial artificial chromosome plasmids. These large plasmids were used to generate new probes, which were then used to generate a higher resolution probe map of the region. One of the BACs was then also used to make an exon trapping library in a minigene plasmid containing a cloning site between splice donor and splice acceptor exons that was transfected into cells from which RNA was extracted and CDNA prepared for polymerase chain reaction (PCR) to detect possibly trapped exons. Two distinct exons were isolated and the DNA was sequenced. The exon sequence was entered into a BLAST search and was found to be $100 \%$ identical to a series of random cDNA clones from different human tissues. The full-length cDNA was isolated and assembled by sequencing and analyzing a large series of independent cDNA clones. Based upon the predicted 403 amino acid open reading frame of the transcript, there was strong homology with the catalytic pocket of many dual-specificity tyrosine and serine/threonine phosphatases with the greatest homology with CDC14. Moreover, the phosphatase domain was within a larger region of the protein that had strong homology with the protein tensin. Examination of other species' DNA sequence available at the time showed that PTEN had a homolog in Saccharomyces cerevisia. Because of its homology with phosphatases and tensin and its location on chromosome 10, the gene was named PTEN.

To obtain genetic evidence that PTEN was the target of the deletions and the candidate tumor suppressor, the exon trap and the BAC probes were used to determine whether any of the homozygous deletions were intragenic. Several homozygous deletions proved to be intragenic by this approach with one in the glioblastoma cell line DBTRG-05 occurring within one of the exon probes. Sequence analysis of the cDNA and exons determined that many of the tumor cell lines were, in fact, harboring missense, nonsense, and frameshift mutations. Examination of glioblastoma samples from patients also showed many similar mutations in the tumor, which were not present in normal tissue matched to the same patient. Analysis of germline DNA from Cowden disease affected family members that they had PTEN mutations affecting the predicted open reading frame in their germline (Liaw et al. 1997). A parallel effort using similar approaches by another group independently identified the PTEN tumor suppressor gene with a demonstration of mutation in a broad range of advanced cancers, which led to their naming the gene, $M M A C 1$, for mutated in multiple advanced cancers 1 (Steck et al. 1997).

While the initial papers documented somatic mutation of PTEN in a wide range of tumor types, follow-up papers by these groups and others rapidly cataloged the range of different tumors and the point in tumor progression when PTEN became mutated. These findings documented that PTEN is mutated in glioblastoma but not lower grade astrocytomas (Wang et al. 1997; Duerr et al. 1998), prostate carcinoma (Wang et al. 1998), breast cancer (Bose et al. 1998), and endometrial carcinoma (Tashiro et al. 1997). Mutation of PTEN was also documented in other human malignancies including lymphoma and cancer of the bladder, head and neck, ovary, thyroid, and gastrointestinal system but at lower frequency (see Ngeow and Eng 2019).

Early biochemical and biological efforts showed that PTEN was a protein phosphatase with selectivity toward negatively charged polypeptide substrates that required this catalytic function to inhibit cell proliferation and activate cell death when it was introduced into cancer cell lines (Furnari et al. 1997; Myers et al. 1997; Li et al. 1998). It was also quickly determined that the PTEN gene protein product was a lipid phosphatase that was able to remove the third inositol phosphate from the substrate $\mathrm{PIP}_{3}$, the product of PI3K (Maehama and Dixon 1998; Myers et al. 1998; Stambolic et al. 1998). Absence of functional PTEN in cells led to elevated levels of $\mathrm{PIP}_{3}$, which activated AKT kinase, and restoration of PTEN using expression vectors lowered $\mathrm{PIP}_{3}$ and AKT signals. Moreover, cell death induced by PTEN in mutant breast or prostate cancer cell lines could be rescued by expression of myrisoylated-AKT, and the ex- 
pression of PTEN in a glioblastoma cell line with mutant PTEN inhibited cell proliferation, which was associated with altered gene expression similar to the pattern seen with an inhibitor of PI3K (Li et al. 1998; Stolarov et al. 2001). Loss of PTEN also activated p70 S6 kinase (Podsypanina et al. 2001). Another function of PTEN that was rapidly appreciated was its ability to inhibit cell migration, which unlike its ability to regulate signaling (AKT, p70S6K) or the phenotypes of cell proliferation and cell death, did not require a functional PTEN phosphatase domain (Tamura et al. 1998). Last, in addition to its phosphatase domain, PTEN was found to have a C2 domain needed for membrane binding and a tail domain that was highly phosphorylated thereby interfering with interaction with the plasma membrane and increasing protein stability (Lee et al. 1999; Vazquez et al. 2000).

Genetic studies in mice were highly informative and showed that pten $^{+/-}$heterozygous mice developed neoplastic lesions in many different organs including epithelial tumors of the prostate, mammary gland, colon, uterus, thyroid, liver, and adrenal gland, as well as hyperplasia of lymph nodes with abnormal expansion of B-cell and T-cell lineages and that these lesions showed evidence of increased phosphorylation and activation of AKT, mTOR, and p70S6K (Di Cristofano et al. 1998; Suzuki et al. 1998; Podsypanina et al. 1999; Stambolic et al. 2000). Because mTOR activated p70S6K kinase in the tumors from pten $^{+/-}$mice, the mice were treated with a rapamycin analog, which lowered p70S6K activity as expected and also inhibited the proliferation of the neoplastic tumor cell lesions in these animals (Podsypanina et al. 2001).

The above studies, which were all published by 2001, form the foundation for the PTEN field. The findings established the identify to the chromosome 10 tumor suppressor, determined that it could regulate cell phenotypes like proliferation, migration, and death and acted as a phosphatase on a signal transduction pathway that could be down-regulated by either restoring PTEN expression or a small molecule inhibitor acting on a kinase including and downstream from PI3K. Research since 2001 has not only built on these findings but has also identified new and unanticipated functions for PTEN.

\section{REFERENCES}

${ }^{*}$ Reference is also in this collection.

Bader AG, Kang S, Vogt PK. 2006. Cancer-specific mutations in PIK3CA are oncogenic in vivo. Proc Natl Acad Sci 103: $1475-1479$. doi: $10.1073 /$ pnas. 0510857103

Baker SJ, Fearon ER, Nigro JM, Hamilton SR, Preisinger AC, Jessup JM, vanTuinen P, Ledbetter DH, Barker DF, Nakamura Y, et al. 1989. Chromosome 17 deletions and p53 gene mutations in colorectal carcinomas. Science 244: 217-221. doi:10.1126/science.2649981

Baker SJ, Markowitz S, Fearon ER, Willson JK, Vogelstein B. 1990. Suppression of human colorectal carcinoma cell growth by wild-type p53. Science 249: 912-915. doi:10 $.1126 /$ science. 2144057

Bellacosa A, Testa JR, Staal SP, Tsichlis PN. 1991. A retroviral oncogene, akt, encoding a serine-threonine kinase containing an SH2-like region. Science 254: 274-277. doi:10 $.1126 /$ science. 1833819

Bellacosa A, de Feo D, Godwin AK, Bell DW, Cheng JQ, Altomare DA, Wan M, Dubeau L, Scambia G, Masciullo $\mathrm{V}$, et al. 1995. Molecular alterations of the AKT2 oncogene in ovarian and breast carcinomas. Int J Cancer 64: 280-285. doi:10.1002/ijc.2910640412

Bernstein A, MacCormick R, Martin GS. 1976. Transformation-defective mutants of avian sarcoma viruses: the genetic relationship between conditional and nonconditional mutants. Virology 70: 206-209. doi:10.1016/ 0042-6822(76)90254-3

Bigner SH, Mark J, Mahaley MS, Bigner DD. 1984. Patterns of the early, gross chromosomal changes in malignant human gliomas. Hereditas 101: 103-113. doi:10.1111/j .1601-5223.1984.tb00455.x

Bigner SH, Mark J, Burger PC, Mahaley MS Jr, Bullard DE, Muhlbaier LH, Bigner DD. 1988. Specific chromosomal abnormalities in malignant human gliomas. Cancer Res 48: 405-411.

Bose S, Wang SI, Terry MB, Hibshoosh H, Parsons R. 1998. Allelic loss of chromosome 10q23 is associated with tumor progression in breast carcinomas. Oncogene 17: 123 127. doi:10.1038/sj.onc. 1201940

Brugge JS, Butel JS. 1975. Role of simian virus 40 gene A function in maintenance of transformation. J Virol 15: 619-635.

Campbell IG, Russell SE, Choong DY, Montgomery KG, Ciavarella ML, Hooi CS, Cristiano BE, Pearson RB, Phillips WA. 2004. Mutation of the PIK3CA gene in ovarian and breast cancer. Cancer Res 64: 7678-7681. doi:10 .1158/0008-5472.CAN-04-2933

Carpenter CL, Duckworth BC, Auger KR, Cohen B, Schaffhausen BS, Cantley LC. 1990. Purification and characterization of phosphoinositide 3-kinase from rat liver. $J$ Biol Chem 265: 19704-19711.

Carpten JD, Faber AL, Horn C, Donoho GP, Briggs SL, Robbins CM, Hostetter G, Boguslawski S, Moses TY, Sav- 
R. Parsons

age S, et al. 2007. A transforming mutation in the pleckstrin homology domain of AKT1 in cancer. Nature 448: 439-444. doi:10.1038/nature05933

Cavenee WK, Dryja TP, Phillips RA, Benedict WF, Godbout R, Gallie BL, Murphree AL, Strong LC, White RL. 1983. Expression of recessive alleles by chromosomal mechanisms in retinoblastoma. Nature 305: 779-784. doi:10 .1038/305779a0

Chang HW, Aoki M, Fruman D, Auger KR, Bellacosa A, Tsichlis PN, Cantley LC, Roberts TM, Vogt PK. 1997. Transformation of chicken cells by the gene encoding the catalytic subunit of PI 3-kinase. Science 276: 18481850. doi:10.1126/science.276.5320.1848

Cheng JQ, Ruggeri B, Klein WM, Sonoda G, Altomare DA, Watson DK, Testa JR. 1996. Amplification of AKT2 in human pancreatic cells and inhibition of AKT2 expression and tumorigenicity by antisense RNA. Proc Natl Acad Sci 93: 3636-3641. doi:10.1073/pnas.93.8.3636

Courtneidge SA, Smith AE. 1983. Polyoma virus transforming protein associates with the product of the $c$-src cellular gene. Nature 303: 435-439. doi:10.1038/303435a0

Cox AD, Der CJ. 2010. Ras history: the saga continues. Small GTPases 1: 2-27. doi:10.4161/sgtp.1.1.12178

DeCaprio JA, Ludlow JW, Figge J, Shew JY, Huang CM, Lee WH, Marsilio E, Paucha E, Livingston DM. 1988. SV40 large tumor antigen forms a specific complex with the product of the retinoblastoma susceptibility gene. Cell 54: 275-283. doi:10.1016/0092-8674(88)90559-4

Di Cristofano A, Pesce B, Cordon-Cardo C, Pandolfi PP. 1998. Pten is essential for embryonic development and tumour suppression. Nat Genet 19: 348-355. doi:10 $.1038 / 1235$

Duerr EM, Rollbrocker B, Hayashi Y, Peters N, MeyerPuttlitz B, Louis DN, Schramm J, Wiestler OD, Parsons R, Eng C, et al. 1998. PTEN mutations in gliomas and glioneuronal tumors. Oncogene 16: 2259-2264. doi:10 $.1038 /$ sj.onc. 1201756

Dulbecco R. 1960. Induction of tumors in vitro with viruses. Natl Cancer Inst Monogr 4: 355-361.

Franke TF, Yang SI, Chan TO, Datta K, Kazlauskas A, Morrison DK, Kaplan DR, Tsichlis PN. 1995. The protein kinase encoded by the Akt proto-oncogene is a target of the PDGF-activated phosphatidylinositol 3-kinase. Cell 81: 727-736. doi:10.1016/0092-8674(95)90534-0

Franke TF, Kaplan DR, Cantley LC, Toker A. 1997. Direct regulation of the Akt proto-oncogene product by phosphatidylinositol-3,4-bisphosphate. Science 275: 665-668. doi:10.1126/science.275.5300.665

Friend SH, Bernards R, Rogelj S, Weinberg RA, Rapaport JM, Albert DM, Dryja TP. 1986. A human DNA segment with properties of the gene that predisposes to retinoblastoma and osteosarcoma. Nature 323: 643-646. doi:10 $.1038 / 323643 \mathrm{a} 0$

Furnari FB, Lin H, Huang HS, Cavenee WK. 1997. Growth suppression of glioma cells by PTEN requires a functional phosphatase catalytic domain. Proc Natl Acad Sci 94: 12479-12484. doi:10.1073/pnas.94.23.12479

Gray IC, Phillips SM, Lee SJ, Neoptolemos JP, Weissenbach J, Spurr NK. 1995. Loss of the chromosomal region 10q23-25 in prostate cancer. Cancer Res 55: 4800-4803.
Gross L. 1974. The role of viruses in the etiology of cancer and leukemia. JAMA 230: 1029-1032. doi:10.1001/jama .1974 .03240070061039

Hahn SA, Schutte M, Hoque AT, Moskaluk CA, da Costa LT, Rozenblum E, Weinstein CL, Fischer A, Yeo CJ, Hruban RH, et al. 1996. DPC4, a candidate tumor suppressor gene at human chromosome 18q21.1. Science 271: 350-353. doi:10.1126/science.271.5247.350

Hansford S, Huntsman DG. 2014. Boveri at 100: Theodor Boveri and genetic predisposition to cancer. J Pathol 234: 142-145.

Harlow E, Whyte P, Franza BR Jr, Schley C. 1986. Association of adenovirus early-region $1 \mathrm{~A}$ proteins with cellular polypeptides. Mol Cell Biol 6: 1579-1589. doi:10.1128/ MCB.6.5.1579

Harris H, Miller OJ, Klein G, Worst P, Tachibana T. 1969. Suppression of malignancy by cell fusion. Nature 223: 363-368. doi:10.1038/223363a0

Huang HJ, Yee JK, Shew JY, Chen PL, Bookstein R, Friedmann T, Lee EY, Lee WH. 1988. Suppression of the neoplastic phenotype by replacement of the RB gene in human cancer cells. Science 242: 1563-1566. doi:10.1126/ science.3201247

Inoki K, Li Y, Zhu T, Wu J, Guan KL. 2002. TSC2 is phosphorylated and inhibited by Akt and suppresses mTOR signalling. Nat Cell Biol 4: 648-657. doi:10.1038/ncb839

James CD, Carlbom E, Dumanski JP, Hansen M, Nordenskjold M, Collins VP, Cavenee WK. 1988. Clonal genomic alterations in glioma malignancy stages. Cancer Res 48: 5546-5551.

Javier RT, Butel JS. 2008. The history of tumor virology. Cancer Res 68: 7693-7706. doi:10.1158/0008-5472 .CAN-08-3301

Juric D, Janku F, Rodón J, Burris HA, Mayer IA, Schuler M, Seggewiss-Bernhardt R, Gil-Martin M, Middleton MR, Baselga J, et al. 2019. Alpelisib plus fulvestrant in PIK3CA-altered and PIK3CA-wild-type estrogen receptor-positive advanced breast cancer: a phase $1 \mathrm{~b}$ clinical trial. JAMA Oncol 5: e184475. doi:10.1001/jamaoncol .2018 .4475

Kamb A, Gruis NA, Weaver-Feldhaus J, Liu Q, Harshman K, Tavtigian SV, Stockert E, Day RS III, Johnson BE, Skolnick MH. 1994. A cell cycle regulator potentially involved in genesis of many tumor types. Science 264: 436-440. doi:10.1126/science.8153634

Kaplan DR, Whitman M, Schaffhausen B, Raptis L, Garcea RL, Pallas D, Roberts TM, Cantley L. 1986. Phosphatidylinositol metabolism and polyoma-mediated transformation. Proc Natl Acad Sci 83: 3624-3628. doi:10.1073/ pnas.83.11.3624

Knudson AG Jr. 1971. Mutation and cancer: statistical study of retinoblastoma. Proc Natl Acad Sci 68: 820-823. doi:10 $.1073 /$ pnas.68.4.820

Lania L, Griffiths M, Cooke B, Ito Y, Fried M. 1979. Untransformed rat cells containing free and integrated DNA of a polyoma nontransforming (Hr-t) mutant. Cell 18: 793802. doi:10.1016/0092-8674(79)90132-6

Lee WH, Bookstein R, Hong F, Young LJ, Shew JY, Lee EY. 1987a. Human retinoblastoma susceptibility gene: cloning, identification, and sequence. Science 235: 1394-1399. doi:10.1126/science.3823889 
Lee WH, Shew JY, Hong FD, Sery TW, Donoso LA, Young LJ, Bookstein R, Lee EY. 1987b. The retinoblastoma susceptibility gene encodes a nuclear phosphoprotein associated with DNA binding activity. Nature 329: 642-645. doi:10.1038/329642a0

Lee JO, Yang H, Georgescu MM, Di Cristofano A, Maehama T, Shi Y, Dixon JE, Pandolfi P, Pavletich NP. 1999. Crystal structure of the PTEN tumor suppressor: implications for its phosphoinositide phosphatase activity and membrane association. Cell 99: 323-334. doi:10.1016/S0092-8674 (00)81663-3

Levine AJ, Oren M. 2009. The first 30 years of p53: growing ever more complex. Nat Rev Cancer 9: 749-758. doi:10 $.1038 / \mathrm{nrc} 2723$

Li J, Yen C, Liaw D, Podsypanina K, Bose S, Wang SI, Puc J, Miliaresis C, Rodgers L, McCombie R, et al. 1997. PTEN, a putative protein tyrosine phosphatase gene mutated in human brain, breast, and prostate cancer. Science 275: 1943-1947. doi:10.1126/science.275.5308.1943

Li J, Simpson L, Takahashi M, Miliaresis C, Myers MP, Tonks N, Parsons R. 1998. The PTEN/MMAC1 tumor suppressor induces cell death that is rescued by the AKT/ protein kinase B oncogene. Cancer Res 58: 5667-5672.

Liaw D, Marsh DJ, Li J, Dahia PL, Wang SI, Zheng Z, Bose S, Call KM, Tsou HC, Peacocke M, et al. 1997. Germline mutations of the PTEN gene in Cowden disease, an inherited breast and thyroid cancer syndrome. Nat Genet 16: 64-67. doi:10.1038/ng0597-64

Lisitsyn N, Lisitsyn N, Wigler M. 1993. Cloning the differences between two complex genomes. Science 259: 946951. doi:10.1126/science. 8438152

Maehama T, Dixon JE. 1998. The tumor suppressor, PTEN/ MMAC1, dephosphorylates the lipid second messenger, phosphatidylinositol 3,4,5-trisphosphate. J Biol Chem 273: 13375-13378. doi:10.1074/jbc.273.22.13375

Manning BD, Tee AR, Logsdon MN, Blenis J, Cantley LC 2002. Identification of the tuberous sclerosis complex-2 tumor suppressor gene product tuberin as a target of the phosphoinositide 3-kinase/akt pathway. Mol Cell 10: 151-162. doi:10.1016/S1097-2765(02)00568-3

Martin GS. 1970. Rous sarcoma virus: a function required for the maintenance of the transformed state. Nature 227: 1021-1023. doi:10.1038/2271021a0

Martin RG, Chou JY. 1975. Simian virus 40 functions required for the establishment and maintenance of malignant transformation. J Virol 15: 599-612.

Myers MP, Stolarov JP, Eng C, Li J, Wang SI, Wigler MH, Parsons R, Tonks NK. 1997. P-TEN, the tumor suppressor from human chromosome 10q23, is a dual-specificity phosphatase. Proc Natl Acad Sci 94: 9052-9057. doi:10 .1073/pnas.94.17.9052

Myers MP, Pass I, Batty IH, Van der Kaay J, Stolarov JP, Hemmings BA, Wigler MH, Downes CP, Tonks NK. 1998. The lipid phosphatase activity of PTEN is critical for its tumor suppressor function. Proc Natl Acad Sci 95: 13513-13518. doi:10.1073/pnas.95.23.13513

Nelen MR, Padberg GW, Peeters EA, Lin AY, van den Helm B, Frants RR, Coulon V, Goldstein AM, van Reen MM, Easton DF, et al. 1996. Localization of the gene for Cowden disease to chromosome 10q22-23. Nat Genet 13: 114-116. doi:10.1038/ng0596-114
* Ngeow J, Eng C. 2019. PTEN in hereditary and sporadic cancer. Cold Spring Harb Perspect Med doi: 10.1101/ cshperspect.a036087

Orye E, Delbeke MJ, Vandenabeele B. 1974. Retinoblastoma and long arm delection of chromosome 13. Attempts to define the deleted segment. Clin Genet 5: 457-464. doi:10 $.1111 /$ j.1399-0004.1974.tb01719.x

Pershouse MA, Stubblefield E, Hadi A, Killary AM, Yung WK, Steck PA. 1993. Analysis of the functional role of chromosome 10 loss in human glioblastomas. Cancer Res 53: 5043-5050.

Podsypanina K, Ellenson LH, Nemes A, Gu J, Tamura M, Yamada KM, Cordon-Cardo C, Catoretti G, Fisher PE, Parsons R. 1999. Mutation of Pten/Mmacl in mice causes neoplasia in multiple organ systems. Proc Natl Acad Sci 96: 1563-1568. doi:10.1073/pnas.96.4.1563

Podsypanina K, Lee RT, Politis C, Hennessy I, Crane A, Puc J, Neshat M, Wang H, Yang L, Gibbons J, et al. 2001. An inhibitor of mTOR reduces neoplasia and normalizes p70/S6 kinase activity in Pten $^{+/}$mice. Proc Natl Acad Sci 98: 10320-10325. doi:10.1073/pnas. 171060098

Rasheed BK, Fuller GN, Friedman AH, Bigner DD, Bigner SH. 1992. Loss of heterozygosity for 10q loci in human gliomas. Genes Chromosomes Cancer 5: 75-82. doi:10 $.1002 /$ gcc. 2870050111

Rous P. 1911. A sarcoma of the fowl transmissible by an agent separable from the tumor cells. J Exp Med 13: 397-411. doi:10.1084/jem.13.4.397

Saal LH, Holm K, Maurer M, Memeo L, Su T, Wang X, Yu JS, Malmstrom PO, Mansukhani M, Enoksson J, et al. 2005. PIK3CA mutations correlate with hormone receptors, node metastasis, and ERBB2, and are mutually exclusive with PTEN loss in human breast carcinoma. Cancer Res 65: 2554-2559. doi:10.1158/0008-5472-CAN-04-3913

Samuels Y, Wang Z, Bardelli A, Silliman N, Ptak J, Szabo S, Yan H, Gazdar A, Powell SM, Riggins GJ, et al. 2004. High frequency of mutations of the PIK3CA gene in human cancers. Science 304: 554. doi:10.1126/science. 1096502

Smith AE, Smith R, Griffin B, Fried M. 1979. Protein kinase activity associated with polyoma virus middle $\mathrm{T}$ antigen in vitro. Cell 18: 915-924. doi:10.1016/0092-8674(79) 90204-6

Srivastava S, Zou ZQ, Pirollo K, Blattner W, Chang EH. 1990. Germ-line transmission of a mutated p53 gene in a cancer-prone family with Li-Fraumeni syndrome. Nature 348: 747-749. doi:10.1038/348747a0

Stambolic V, Suzuki A, de la Pompa JL, Brothers GM, Mirtsos C, Sasaki T, Ruland J, Penninger JM, Siderovski DP, Mak TW. 1998. Negative regulation of PKB/Akt-dependent cell survival by the tumor suppressor PTEN. Cell 95: 29-39. doi:10.1016/S0092-8674(00)81780-8

Stambolic V, Tsao MS, Macpherson D, Suzuki A, Chapman WB, Mak TW. 2000. High incidence of breast and endometrial neoplasia resembling human Cowden syndrome in pten $^{+/-}$mice. Cancer Res 60: 3605-3611.

Steck PA, Ligon AH, Cheong P, Yung WK, Pershouse MA. 1995. Two tumor suppressive loci on chromosome 10 involved in human glioblastomas. Genes Chromosomes Cancer 12: 255-261. doi:10.1002/gcc.2870120404

Steck PA, Pershouse MA, Jasser SA, Yung WK, Lin H, Ligon AH, Langford LA, Baumgard ML, Hattier T, Davis T, et al. 
R. Parsons

1997. Identification of a candidate tumour suppressor gene, MMAC1, at chromosome 10q23.3 that is mutated in multiple advanced cancers. Nat Genet 15: 356-362. doi:10.1038/ng0497-356

Stehelin D, Varmus HE, Bishop JM, Vogt PK. 1976. DNA related to the transforming gene(s) of avian sarcoma viruses is present in normal avian DNA. Nature 260: 170173. doi:10.1038/260170a0

Stolarov J, Chang K, Reiner A, Rodgers L, Hannon GJ, Wigler MH, Mittal V. 2001. Design of a retroviral-mediated ecdysone-inducible system and its application to the expression profiling of the PTEN tumor suppressor. Proc Natl Acad Sci 98: 13043-13048. doi:10.1073/pnas.221 450598

Suzuki A, de la Pompa JL, Stambolic V, Elia AJ, Sasaki T, del Barco Barrantes I, Ho A, Wakeham A, Itie A, Khoo W, et al. 1998. High cancer susceptibility and embryonic lethality associated with mutation of the PTEN tumor suppressor gene in mice. Curr Biol 8: 1169-1178. doi:10.1016/ S0960-9822(07)00488-5

Tamura M, Gu J, Matsumoto K, Aota S, Parsons R, Yamada KM. 1998. Inhibition of cell migration, spreading, and focal adhesions by tumor suppressor PTEN. Science 280: 1614-1617. doi:10.1126/science.280.5369.1614

Tashiro H, Blazes MS, Wu R, Cho KR, Bose S, Wang SI, Li J, Parsons R, Ellenson LH. 1997. Mutations in PTEN are frequent in endometrial carcinoma but rare in other common gynecological malignancies. Cancer Res 57: 39353940.

Tee AR, Fingar DC, Manning BD, Kwiatkowski DJ, Cantley LC, Blenis J. 2002. Tuberous sclerosis complex-1 and -2 gene products function together to inhibit mammalian target of rapamycin (mTOR)-mediated downstream signaling. Proc Natl Acad Sci 99: 13571-13576. doi:10.1073/ pnas.202476899
Tegtmeyer P. 1975. Function of simian virus 40 gene $\mathrm{A}$ in transforming infection. J Virol 15: 613-618.

Treisman R, Novak U, Favaloro J, Kamen R. 1981. Transformation of rat cells by an altered polyoma virus genome expressing only the middle-T protein. Nature 292: 595600. doi:10.1038/292595a0

Vazquez F, Ramaswamy S, Nakamura N, Sellers WR. 2000. Phosphorylation of the PTEN tail regulates protein stability and function. Mol Cell Biol 20: 5010-5018. doi:10 .1128/MCB.20.14.5010-5018.2000

Wang SI, Puc J, Li J, Bruce JN, Cairns P, Sidransky D, Parsons R. 1997. Somatic mutations of PTEN in glioblastoma multiforme. Cancer Res 57: 4183-4186.

Wang SI, Parsons R, Ittmann M. 1998. Homozygous deletion of the PTEN tumor suppressor gene in a subset of prostate adenocarcinomas. Clin Cancer Res 4: 811-815.

Whitman M, Kaplan DR, Schaffhausen B, Cantley L, Roberts TM. 1985. Association of phosphatidylinositol kinase activity with polyoma middle-T competent for transformation. Nature 315: 239-242. doi:10.1038/315239a0

Whitman M, Kaplan D, Roberts T, Cantley L. 1987. Evidence for two distinct phosphatidylinositol kinases in fibroblasts. Implications for cellular regulation. Biochem J 247: 165-174. doi:10.1042/bj2470165

Whitman M, Downes CP, Keeler M, Keller T, Cantley L. 1988. Type I phosphatidylinositol kinase makes a novel inositol phospholipid, phosphatidylinositol-3-phosphate. Nature 332: 644-646. doi:10.1038/332644a0

Whyte P, Buchkovich KJ, Horowitz JM, Friend SH, Raybuck M, Weinberg RA, Harlow E. 1988. Association between an oncogene and an anti-oncogene: the adenovirus E1A proteins bind to the retinoblastoma gene product. Nature 334: 124-129. doi:10.1038/334124a0 


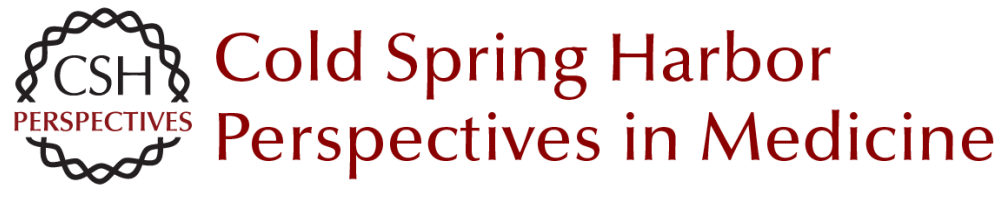

\title{
Discovery of the PTEN Tumor Suppressor and Its Connection to the PI3K and AKT Oncogenes
}

\author{
Ramon Parsons
}

Cold Spring Harb Perspect Med 2020; doi: 10.1101/cshperspect.a036129 originally published online January 13, 2020

\section{Subject Collection The PTEN Family}

\section{PTEN in Regulating Hematopoiesis and \\ Leukemogenesis \\ Yilin Wu, Haichuan Zhu and Hong Wu}

Connecting Genotype with Behavioral Phenotype

in Mouse Models of Autism Associated with

PTEN Mutations

Amy E. Clipperton-Allen and Damon T. Page

Metabolic Role of PTEN in Insulin Signaling and

Resistance

Yu Zhe Li, Antonio Di Cristofano and Minna Woo

Posttranslational Regulation and Conformational

Plasticity of PTEN

Larissa Kotelevets, Barbara Trifault, Eric Chastre, et al.

Toward Systems Pathology for PTEN Diagnostics Nahal Haddadi, Glena Travis, Najah T. Nassif, et al.

PTEN in Hereditary and Sporadic Cancer Joanne Ngeow and Charis Eng

PTEN Mouse Models of Cancer Initiation and

Progression

Yu-Ru Lee and Pier Paolo Pandolfi

Dual-Specific Protein and Lipid Phosphatase

PTEN and Its Biological Functions

Taojian Tu, Jingyu Chen, Lulu Chen, et al.
PTEN: Bridging Endocytosis and Signaling Matthew F. Lee and Lloyd C. Trotman

PTEN as a Guardian of the Genome: Pathways and Targets

Xinyi Fan, Jeffrey Kraynak, Jonathan P.S. Knisely, et al.

Discovery of the PTEN Tumor Suppressor and Its

Connection to the PI3K and AKT Oncogenes Ramon Parsons

The Complex Landscape of PTEN mRNA

Regulation Erin Sellars, Martino Gabra and Leonardo Salmena

PTEN Nuclear Functions Jason Ho, Edward S. Cruise, Ryan J.O. Dowling, et al.

Structural Mechanisms of PTEN Regulation Glenn R. Masson and Roger L. Williams

PTEN in Chromatin Remodeling Jingyi Yang and Yuxin Yin

The Role of PTEN in Innate and Adaptive Immunity

Henry Taylor, Arian D. J. Laurence and Holm H. Uhlig

For additional articles in this collection, see http://perspectivesinmedicine.cshlp.org/cgi/collection/ 